\title{
Analisis hubungan antara kecerdasan emosional dengan kedisiplinan siswa sekolah dasar
}

\author{
Larasaty Indah Kumalasari*, Sigit Dwi Kusrahmadi, Herwin Herwin \\ Pendidikan Sekolah Dasar, Universitas Negeri Yogyakarta \\ *Corresponding Author. e-mail: larasatyindah52@gmail.com
}

\begin{abstract}
Abstrak
Penelitian ini bertujuan untuk mengetahui hubungan antara kecerdasan emosional dengan kedisiplinan siswa kelas tinggi. Penelitian ini menggunakan pendekatan kuantitatif korelasi ex-post facto. Populasi dalam penelitian ini adalah siswa kelas tinggi SD Negeri se-Gugus Barenglor yang berjumlah 374 siswa dengan sampel penelitian berjumlah 193 siswa yang ditentukan menggunakan rumus Slovin. Teknik pengumpulan data menggunakan skala psikologi. Instrumen pengumpulan data menggunakan skala kedisiplinan dan kecerdasan emosional. Instrumen ini diujicobakan kepada 159 responden. Uji validitas instrumen menggunakan validitas isi dengan teknik expert judgement, sedangkan daya beda dihitung menggunakan korelasi aitem total terkoreksi. Uji reliabilitas menggunakan rumus Alpha Cronbach. Uji prasyarat analisis menggunakan uji normalitas dan linearitas. Teknik analisis data yang digunakan adalah analisis korelasi product moment. Hasil penelitian menunjukkan bahwa terdapat hubungan positif antara kecerdasan emosional dengan kedisiplinan.
\end{abstract}

Kata kunci: kecerdasan emosional, kedisiplinan, siswa sekolah dasar

\begin{abstract}
This study aims to determine the relationship between emotional intelligence and the discipline of high-grade students. This study uses a quantitative approach to ex-post facto correlation. The population in this study were the high-grade students of SD Negeri as Barenglor Cluster, amounting to 374 students with a research sample of 193 students who were determined using the Slovin formula. Data collection techniques using a psychological scale. The data collection instrument used a scale of discipline and emotional intelligence. This instrument was tested on 159 respondents. The validity test of the instrument uses content validity with expert judgment techniques, while the discriminant index is calculated using the total corrected item correlation. Reliability test using Alpha Cronbach formula. The prerequisite analysis test used the normality and linearity test. The data analysis technique used is the product moment correlation analysis. The results showed that there was a positive relationship between emotional intelligence and discipline.
\end{abstract}

Keywords: emotional intelligence, discipline, elementary school students 


\section{PENDAHULUAN}

Karakter merupakan salah satu aspek yang tidak bisa dilupakan dan dipisahkan dalam kehidupan manusia khususnya bagi anak-anak. Pendidikan karakter merupakan proses yang berlangsung mulai dari anak-anak hingga dewasa, hal ini sesuai dengan yang dikemukakan oleh Megawangi (2007, p.2) bahwa proses pembentukan karakter berlangsung secara terus menerus bahkan seumur hidup. Konsep karakter harus menjadi akar serta roh pembangunan akhlak yang dimiliki oleh Bangsa Indonesia, pernyataan tersebut sejalan dengan yang dikemukakan oleh Narwanti (2011, p.14) konsep pendidikan karakter diharapkan menjadi roh dari pembangunan bangsa dan negara.

Maka dari itu, konsep besar pendidikan karakter dinyatakan menjadi program kegiatan yang harus dilaksanakan serta penting untuk dikuatkan dalam kehidupan berbangsa dan bernegara. Penguatan karakter menjadi salah satu program prioritas pemerintah dalam melakukan revolusi karakter bangsa. Kementerian Pendidikan dan Kebudayaan yang telah dilakukan sejak tahun 2016. Gerakan PPK menempati kedudukan fundamental dan strategis pada saat pemerintah mencanangkan revolusi karakter bangsa. PPK juga merupakan poros utama perbaikan pendidikan nasional. Terdapat lima nilai utama karakter sebagai poros pendidikan yaitu religius, integritas, mandiri, nasionalis, dan gotong royong.

Karakter utama yang telah disebutkan memiliki aspek-aspek turunan, religius memiliki aspek-aspek turunan yaitu beriman bertaqwa, bersih, toleransi, dan cinta lingkungan. Nasionalis memiliki aspek-aspek turunan cinta tanah air, semangat kebangsaan, dan menghargai kebhinekaan. Integritas memiliki aspek turunan yaitu kejujuran, keteladanan, kesantunan, cinta pada kebenaran.. Mandiri memiliki nilai aspek turunan yaitu kerja keras, kreatif, disiplin, berani, pembelajar. Gotong royong memiliki aspek turunan yaitu kerjasama, solidaritas, saling menolong,dan kekeluargaan.

Wuyandani (2014, p.286) mengatakan bahwa karakter kedisiplinan sangatlah penting dimiliki oleh manusia agar nantinya akan memunculkan nilai-nilai karakter baik lainnya. Kedisiplinan merupakan perilaku seseorang yang terkontrol, terkendali serta seseuai dengan aturan yang berlaku. Kedisiplinan merupakan aspek cerminan dari kepatuhan, sesuai dengan yang dikemukakan oleh Zuriah (2011, p.69) mengemukakan bahwa kedisiplinan merupakan sikap serta perilaku cerminan dari kepatuhan, ketaatan, ketertiban, kesetiaan, ketelitian, dan keteraturan perilaku seseorang terhadap aturan yang berlaku.

Permasalahan yang ditemukan di lapangan menunjukkan masih adanya ketidakpedulian siswa terkait dengan kedisiplinan di sekolah. Hal tersebut dibuktikan dengan kurang tepatnya datang ke sekolah bahkan masih ada pulang lebih cepat. Selain itu masih ditemukannya siswa yang tidak bereseragam lengkap hingga tidak melaksanakan piket sesuai dengan jadwalnya. Pada kegiatan pembelajaran juga masih ditemukan siswa yang kurang disiplin misalnya tidak mengerjakan tugas yang diberikan, saling mengganggu pada saat kegiatan pembelajaran bahkan mengucapkan kata kasar pada saat kegiatan pembelajaran berlangsung.

Karakter kedisiplinan sangatlah berperan bagi pembentukan sikap yang dimiliki oleh seseorang. Hal ini sesuai dengan yang dikemukakan oleh Munawaroh (2013, p.39) karakter kedisiplinan sangatlah penting dalam membentuk kepribadian serta karakter seseorang menjadi lebik baik dan bertanggung jawab, membina seseorang menjadi seseorang yang taat pada peraturan yang ada. Pembentukan karakter berasal dari berbagai pihak salah satunya berasal dari kecerdasan emosional atau Emotional Quotient (EQ), sesuai dengan pendapat yang dikemukakan oleh Goleman (2000, p.44) bahwa kecerdasan emosional dapat mengembangkan sikap atau karakter yang dimiliki oleh anak.

Kecerdasan emosional juga sangat berperan dalam peningkatan prestasi belajar siswa, sejalan dengan yang dikemukakan Marhaeni (2016, p.337) dalam proses pembelajaran, kecerdasan emosioal sangatlah diperlukan oleh siswa untuk memahami pelajaran yang disampaikan oleh guru, karena intelektualitas saja tidak dapat berfungsi dengan sebaik-baiknya tanpa adanya penghayatan emosi pada setiap pelajaran. Hal tersebut diperkuat dengan pendapat yang dikemukakan oleh Goleman (2009, p.47) menyatakan bahwa kecerdasan emosional menentukan seberapa baik siswa mampu menggunakan kecerdasan-kecerdasan yang lain yang dimiliki termasuk IQ. 
Seseorang yang memiliki kecerdasan emosi yang tinggi akan mempunyai sikap disiplin yang kuat (Wizman, 2017, p.136). Berkaitan dengan latar belakang di atas, penulis tertarik untuk melakukan penelitian mengetahui hubungan kecerdasan emosional dengan karakter kedisiplinan siswa. Penelitian ini dikhususkan untuk siswa SD kelas tinggi untuk mengetahui sejauh mana kecerdasan emosional memberikan peran bagi kedisiplinan siswa.

\section{METODE PENELITIAN}

Penelitian ini menggunakan pendekatan kuantitaif. Jenis penelitian ini menggunakan penelitian ex-post facto. Data pada penelitian ini diukur menggunakan angka-angka serta analisis statistik. Penelitian ini bertujuan untuk mengetahui ada tidaknya hubungan antara kecerdasan emosional dengan kedisiplinan siswa SD Negeri se-Gugus Barenglor Klaten. Penelitian ini akan dilaksanakan pada bulan Maret 2020, yaitu pada semester genap tahun ajaran 2020/2021. Tempat penelitian berada di Sekolah Dasar se-Gugus Barenglor adalah SD Negeri Barenglor 1, SD Negeri Barenglor 3, dan SD Negeri Barenglor 4. SD Negeri se-Gugus Barenglor, Kecamatan Klaten Utara, Kabupaten Klaten dipilih menjadi lokasi penelitian dikarenakan ditemukan permasalah sesuai dengan variabel kedisiplinan dan kecerdasan emosional.

Populasi pada penelitian ini adalah seluruh siswa kelas tinggi di SD Negeri se-Gugus Barenglor Kecamatan Klaten Utara Kabupaten Klaten yang berjumlah 374 siswa. Alasan peneliti menggunakan subjek penelitian kelas tinggi karena kelas tinggi memiliki pemikiran yang logis serta rasional sejalan dengan yang dikemukakan oleh Lewis $(2004$, p.182) mengatakan bahwa rentang usia kelas tinggi antara 9-14 tahun merupakan rentang usia yang umumnya bersikap lebih logis, kritis dan berusaha menyenangkan orang lain. Pengambilan sampel dalam penelitian ini adalah dengan menggunakan teknik simple random sampling. Penelitian ini menggunakan sampel yaitu siswa kelas IV,V,dan VI SD Negeri se-gugus Barenglor yang masing-masing SD diambil sampelnya, sebanyak 193 siswa. Besaran sampel pada penelitian ini dilakukan dengan menggunakan teknik Slovin dengan sampling error sebesar 5\%.

Teknik pengumpulan data yang digunakan dalam penelitian ini untuk mendapatkan data yaitu dengan kuisioner. Pada peneliti ini akan digunakan instrumen skala kedisiplinan 30 item untuk mengukur variabel kedisiplinan dan 30 item untuk mengukur variabel kecerdasan emosional. Adapun teknik analisis data yang digunakan adalah analisis data deskriptif dan analisis data inferensial. Sebelum dilakukan analisis inferensial terlebih dahulu dilakukan pengujian normalitas data dengan menggunakan teknik Kolmogorov Smirnov. Adapun kriteria yang digunakan ialah data berdistribusi norma jika $p$ value > 0,05 (Purwaningsih \& Herwin, 2020); (Pangestu, Sujati \& Herwin, 2020); (Saputri \& Herwin, 2020); (Tjabolo \& Herwin, 2020).

\section{HASIL DAN PEMBAHASAN}

Hasil pengukuran pada skala kedisiplinan diperoleh 193 siswa kelas tinggi SD se-gugus Barenglor yang terdiridari 55 siswa kelas IV, 73 siswa kelas V, dan 65 siswa kelas VI. Jumlah butir skala kedisiplinan adalah 28 butir pernyataan dengan lima pilihan atau skala jawaban yaitu selalu, sering, kadang-kadang, jarang, tidak pernah. Penskoran untuk pernyataan favourable yaitu 5 untuk selalu, 4 untuk sering, 3 untuk kadang-kadang, 2 untuk jarang, dan 1 untuk tidak pernah, sedangkan untuk skala unfavourable yaitu 1 untuk selalu, 2 untuk sering, 3 untuk kadang-kadang, 4 untuk jarang, dan 5 untuk tidak pernah. Data penelitian variabel kedisiplinan diolah menggunakan SPSS 2. Berdasarkan olah data yang dilakukan oleh peneliti dengan bantuan SPSS 22, dapat dideskripsikan data penelitian variabel kedisiplinan memiliki nilai rata-rata (mean) sebesar 108,91, nilai tengah (median) sebesar 109,00, nilai yang sering muncul (mode) sebesar 114, simpangan baku (std. deviation) sebesar 10,559, rentang (range) sebesar 64, skor terendah (minimum) sebesar 75 dan skor tertinggi (maksimum) sebesar 139. Distribusi frekuensi kedisiplinan dilakukan dengan menentukan kelas interval yang diperoleh hasil banyak kelas 9 serta panjang interval 8 . 
Tabel 1. Distribusi Frekuensi Kedisiplinan

\begin{tabular}{llll}
\hline No & Interval Skor & Frekuensi & Frekuensi \% \\
\hline 1 & $75-82$ & 2 & 1,04 \\
2 & $83-90$ & 5 & 2,59 \\
3 & $91-98$ & 24 & 12,43 \\
4 & $99-106$ & 53 & 27,46 \\
5 & $107-114$ & 53 & 27,46 \\
6 & $115-122$ & 33 & 17,1 \\
7 & $123-130$ & 20 & 10,36 \\
8 & $131-138$ & 2 & 1,04 \\
9 & $139-146$ & 1 & 0,52 \\
\hline \multicolumn{2}{l}{ Jumlah } & 193 & 100 \\
\hline
\end{tabular}

Berdasarkan penyajian data tersebut, siswa dengan skor kedisiplinan 78-82 ada 2 siswa, 8390 ada 5 siswa, 91-98 ada 24 siswa, 99-106 ada 53 siswa, 107-114 ada 53 siswa, 115-122 ada 33 siswa, 123-130 ada 20 siswa, 131-138 ada 2 siswadan 139-146 ada 1 siswa. Selain itu data hasil pengukuran juga disajikan dalam diagram batang sebagai berikut.

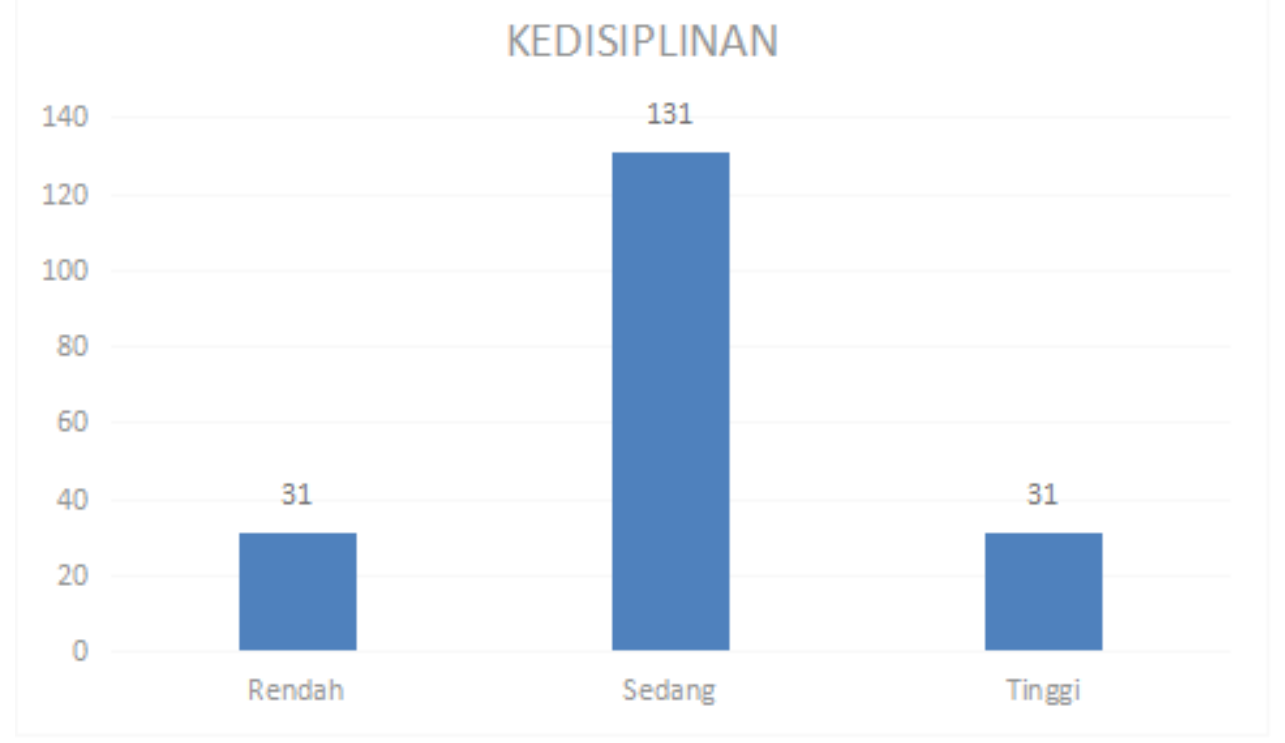

Gambar 1. Diagram Variabel Kedisiplinan

Berdasarkan informasi dari penyajian data tersebut, diketahui variabel kedisiplinan pada kategori rendah sebanyak 31 siswa $(16,1 \%)$, kategori sedang sebanyak 131 siswa $(67,8 \%)$, dan kategori tinggi sebanyak 31 siswa $(16,1 \%)$. Variabel Kedisiplinan dapat disimpulkan pada siswa kelas tinggi SD Negeri Se-Gugus Barenglor Klaten termasuk dalam kategori sedang.

Hasil pengukuran pada skala kecerdasan emosional diperoleh 193 siswa kelas tinggi SD segugus Barenglor yang terdiri dari 55 siswa kelas IV, 73 siswa kelas V, dan 65 siswa kelas VI. Jumlah butir skala kedisiplinan adalah 28 butir pernyataan dengan lima pilihan atau skala jawaban yaitu selalu, sering, kadang-kadang, jarang, tidak pernah. Penskoran untuk pernyataan favourable yaitu 5 untuk selalu, 4 untuk sering, 3 untuk kadang-kadang, 2 untuk jarang, dan 1 untuk tidak pernah, sedangkan untuk skala unfavourable yaitu 1 untuk selalu, 2 untuk sering, 3 untuk kadang-kadang, 4 untuk jarang, dan 5 untuk tidak pernah. Data penelitian variabel kecerdasan emosional diolah menggunakan SPSS 22. Berdasarkan olah data yang dilakukan dapat dideskripsikan data penelitian variabel kecerdasan emosional memiliki nilai rata-rata (mean) sebesar 108,75, nilai tengah (median) 
sebesar 109,00, nilai yang sering muncul (mode) sebesar 105, simpangan baku (std. deviation) sebesar 11,263, rentang (range) sebesar 58, skor terendah (minimum) sebesar 78 dan skor tertinggi (maksimum) sebesar 134. Distribusi frekuensi kedisiplinan dilakukan dengan menentukan kelas interval yang diperoleh hasil banyak kelas 9 serta panjang interval 7.

Tabel 2. Distribusi Frekuensi Kecerdasan Emosional

\begin{tabular}{llll}
\hline No & Interval Skor & Frekuensi & Frekuensi \% \\
\hline 1 & $78-84$ & 7 & 3,63 \\
2 & $85-91$ & 6 & 3,11 \\
3 & $92-98$ & 19 & 9,84 \\
4 & $99-105$ & 46 & 23,84 \\
5 & $106-112$ & 41 & 21,24 \\
6 & $113-119$ & 41 & 21,24 \\
7 & $120-126$ & 21 & 10,88 \\
8 & $127-133$ & 11 & 5,70 \\
9 & $134-140$ & 1 & 0,52 \\
\hline Jumlah & 193 & 100 \\
\hline
\end{tabular}

Berdasarkan pada penyajian data tersebut, siswa dengan skor kecerdasan emosional 78-84 ada 7 siswa, 85-91 ada 6 siswa, 92-98 ada 19 siswa, 99-105 ada 46 siswa, 106-112 ada 41 siswa, 113-119 ada 41 siswa, $120-126$ ada 21 siswa, $127-133$ ada 11 siswa dan 134-140 ada 1 siswa. Selain itu hasil pengukuran pada variabel kecerdasan emosional juga disajikan dalam bentuk diagram batang sebagai berikut.

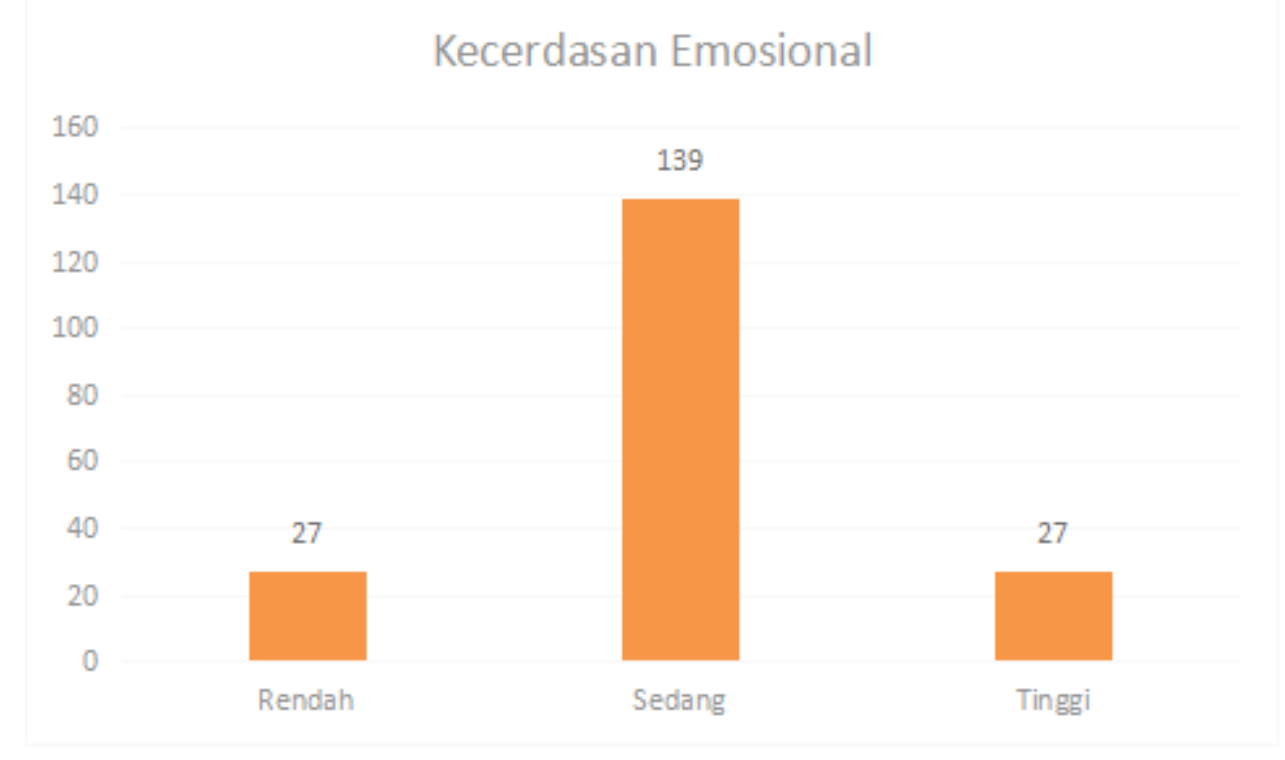

Gambar 2. Diagram Variabel Kecerdasan Emosional

Berdasarkan pada diagram tersebut, diketahui variabel kecerdasan emosional pada kategori rendah sebanyak 27 siswa (14\%), kategori sedang sebanyak 139 siswa (72\%), dan kategori tinggi sebanyak 27 siswa (14\%). Variabel Kecerdasan Emosinoal dapat disimpulkan pada siswa kelas tinggi SD Negeri Se-Gugus Barenglor Klaten termasuk dalam kategori sedang.

Sebelum melakukan analisis parametrik, terlebih dahulu dilakukan pengujian normalitas data. Uji normalitas dilakukan untuk mengetahui kedua variabel yaitu variabel bebas dan variabel terikat yang diteliti berdistribusi normal. Pengujian dilakukan menggunakan SPSS 22. Variabel tersebut berdistribusi normal atau tidak jika nilai sig lebih dari 0,05 , maka variabel bebas dan terikat berdistribusi normal. Hasil pengujian diperoleh bahwa variabel kedisiplinan memiliki nilai sig sebesar 0,200 sedangkan variabel kecerdasan emosional memiliki nilai sig sebesar 0,200 , sehingga dapat disimpulkan bahwa kedua variabel penelitian berdistribusi normal. 
Uji lineratitas dilakukan untuk mengetahui pola hubungan yang linaer atau tidak antara kedua variabel yaitu variabel bebas dan variabel terikat. Pengujian dilakukan menggunakan SPSS 22. Variabel tersebut linear atau tidak jika nilai sig linearity kurang dari 0,05 dan sig deviation of linearity lebih dari 0,05, maka hubungan antara variabel bebas dan terikat tersebut linear. Berdasarkan hasil pengujian diperoleh bahwa hubungan antara dua variabel kecerdasan emosional (X) dengan Kedisiplinan (Y) dengan taraf signifikansi linearity sebesar 0,000 dan signifikansi deviation linearity sebesar 0,419, sehingga disimpulkan bahwa hubungan kedua variabel tersebut linier.

Pengujian hipotesis penelitian ini menggunakan teknik analisis korelasi product moment. Rumusan masalah pada penelitian ini adalah "terdapat hubungan postif antara kecerdasan emosional dengan kedisiplinan siswa kelas tinggi SD Negeri Se-Gugus Barenglor". Berdasarkan hasil analisis dapat diketahui bahwa $r_{\text {hit }}$ yang dihasilkan sebesar 0,823 dengan signifikansi $<0.05$. Nilai $r_{\text {hit }}$ mendekati 1 sehingga dapat dikatakan bahwa terdapat hubungan positif antara variabel bebas dan variabel terikat. Sehingga dapat disimpulkan bahwa terdapat hubungan positif antara kecerdasan emosional dengan kedisiplinan siswa kelas tinggi SD Negeri Se-Gugus Barenglor Klaten sebesar 0,823. Jika diterjemahkan dalam koofisien korelasi, maka nilai korelasi antara kecerdasan emosional dengan kedisiplinan sebesar 0,823 berada diantara 0,800-1,00 sehingga termasuk dalam kategori sangat kuat.

Hasil analisis deskripsi penelitian setelah melakukan analisis data statistik menunjukkan presentasi data variabel penelitian kedisiplinan siswa kelas tinggi yang diperoleh di SD Negeri SeGugus Barenglor Klaten dikategorikan sedang dengan presentasi 67,8\%. Skor indikator tertinggi dari variabel penelitian kedisiplinan adalah indikator taat terhadap peraturan lisan yang berlaku dengan skor $20,76 \%$, sedangkan skor indikator terendah adalah indikator taat terhadap peraturan tertulis yang berlaku dengan skor $19,11 \%$.

Indikator tertinggi pada variabel penelitian kedisiplinan adalah taat terhadap peraturan lisan yang berlaku dengan butir nomor 8 , butir penyataannya yaitu "saya membawa buku pelajaran sesuai dengan jadwal yang telah disusun oleh guru". Pernyataan tersebut memiliki skor mean butir tertinggi dari seluruh pernyataan dan banyak siswa kelas tinggi SD Se-Gugus Barenglor Klaten mengisi pada kolom "selalu". Hal tersebut menunjukkan bahwa sebagian besar siswa kelas tinggi mematuhi peraturan lisan yang mereka buat dengan guru kelas masing-masing dan mereka mempersiapkan buku sesuai dengan jadwal pelajaran esok hari.

Pernyataan "saya membawa buku pelajaran sesuai dengan jadwal yang telah disusun oleh guru" memiliki skor tertinggi dapat disebabkan karena sebagian besar didalam diri siswa tertanam sifat kedisiplinan yang memiliki ciri-ciri sesuai dengan yang dikemukakan oleh Tu'u (2004, p.38) kedisiplinan memiliki ciri-ciri yaitu mengatur waktu belajar, rajin dan teratur belajar, perhatian yang baik saat belajar dikelas, dan ketertiban diri saat belajar. Sejalan dengan pendapat yang di kemukakan oleh Sulistiowati (2001, p.3) bahwa sisw belajar dengan baik maka terdapat beberapa kedisiplinan yang harus dimiliki salah satunya yaitu kedisiplinan dalam menepati jadwal yang telah dibuat, dalam hal ini siswa telah diperintahkan untuk membuat jadwal belajar oleh guru kelas kemudian siswa akan mematuhi guru dengan mempersiapkan jadwal pelajaran esok hari.

Keinginan siswa untuk patuh serta mengormati guru juga terlihat dengan jelas, Naim (2012, p.147) berpendapat bahwa kedisiplinan merupakan kepatuhan untuk menghormati, melaksanakan serta mengharuskan seseorang tunduk kepada keputusan, perintah, dan peraturan yang berlaku, sehingga siswa akan menghormati guru apabila mereka patuh terhadap peraturan yang dibuat bersama. Kedisiplinan sangatlah penting dikembangkan bagi anak agar mereka nantinya dapat tumbuh dan berkembang menjadi pribadi yang patuh dan bertanggung jawab kepada sesama.

Skor indikator terendah pada variabel penelitian kedisiplinan yaitu taat terhadap peraturan tertulis yang berlaku dengan butir nomor 1 yaitu "Saya rajin berangkat sekolah" pernyataan tersebut yang merupakan skor mean butir terendah dari seluruh butir pernyataan, artinya banyak siswa kelas tinggi yang memilih kolom "jarang" dan "tidak pernah". Hal ini membuktikan bahwa siswa tidak rajin dan tidak suka berangkat ke sekolah atau sering disebut dengan school refusal .

Ampuni \& Andayani (2015) menegaskan bahwa penyebab school refusal atau penolakan sekolah yaitu ketidakdisiplinan waktu yang dilakukan oleh siswa, padahal kedisiplinan waktu 
maupun perbuatan haruslah dilakukan dan diterapkan sejak dini salah satunya adalah rajin berangkat ke sekolah. Hal ini sejalan dengan pendapat yang dikemukakan oleh Moenir (2010, p.96) salah satu perilaku yang mencerminkan kedisiplinan waktu yaitu berangkat ke sekolah sesuai dengan tata tertib yang berlaku, menjadikan siswa rajin berangkat sekolah memang tidak mudah perlu metode yang tepat serta bantuan dari berbagai pihak untuk melakukannya, sejalan dengan Rochimi \& Suismanto (2018) metode keteladan merupakan salah satu metode yang tepat untuk meningkatkan kedisiplinan siswa karena metode ini mencotonhkan secara langsung dan real kepada anak, seperti guru berangkat lebih awal dan rajin berangkat ke sekolah.

Hasil analisis deskripsi setelah melakukan analisis data statistik menunjukkan presentasi data variabel penelitian kecerdasan emosional siswa kelas tinggi yang diperoleh di SD Negeri SeGugus Barenglor Klaten dikategorikan sedang dengan presentase 72\%. Skor indikator tertinggi dari variabel penelitian kecerdasan emosional adalah indikator mengenali emosi orang lain dengan skor $20,96 \%$ sedangkan skor terendah adalah indikator mengelola emosi dengan skor 18,48\%. Indikator tertinggi pada variabel penelitian kecerdasan emosional adalah memotivasi diri yang dengan butir nomor 18 , butir pernyataannya yaitu " saya tidak perduli dengan masa depan saya". pernyataan tersebut merupakan skor mean butir tertinggi dari seluruh pernyataan tersebut dan banyak siswa kelas tinggi SD Negeri Se-Gugus Barenglor Klaten mengisi pada kolom "tidak pernah". Hal tersebut menunjukkan bahwa sebagian besar siswa kelas tinggi sangat perduli dengan masa depannya. Motivasi yang dimaksudkan disini yaitu siswa kelas tinggi SD Negeri Se-Gugus Barenglor memiliki dorongan untuk berprestasi yang sangat bermanfaat bagi masa depan mereka karena didalam diri siswa terdapat elemen-elemen kecerdasan emosional, sesuai dengan yang dikemukakan oleh Goleman (2000, p.58) kecerdasan emosional memiliki beberapa elemen yaitu salah satunya yaitu motivasi. Sejalan dengan hal tersebut Efendi (2005, p.191) tindakan memotivasi harus dilakukan dengan menyentuh emosi, karena emosi yang negatif dan kurang baik pasti akan menghasilkan tindakan yang negatif begitu juga sebaliknya, emosi yang positif atau baik pasti akan menghasilkan tindakan yang positif salah satunya yaitu memotivasi diri sendiri untuk peduli terhadap masa depan. Dengan hasil yang ditunjukan terlihat bahwa siswa sangat perduli terhadap masa depan mereka.

Skor indikator terendah pada variabel penelitian kecerdasan emosional yaitu mengenali emosi diri dengan butir nomor 1 yaitu "saya menangis ketika melihat sesuatu yang menyedihkan" pernyataan tersebut yang merupakan skor mean butir terendah dari seluruh butir pernyataan, artinya banyak siswa kelas tinggi yang memilih kolom "jarang" dan "tidak pernah". Hal ini membuktikan bahwa siswa tidak mengenali emosi mereka dengan baik. Kecerdasan emosional diartikan mampu membuat seseorang mengenal emosi yang terjadi dalam dirinya, sesuai dengan teori yang dikemukakan oleh Goleman (2000, p.59) mengatakan bahwa mengenali emosi diri merupakan kemampuan untuk dapat mengartikan dan menamai emosi tersebut diikuti dengan perubahan tingkah laku yang menyertai perasaan didalam diri mereka. Sejalan dengan teori yang dikemukakan oleh Manizar (2016, p.5) bahwa salah satu fungsi kecerdasan emosional yaitu menyesuaikan reaksi dengan kondisi khusus. Sedih atau menangis merupakan reaksi yang tepat ketika terdapat kondisi yang menyedihkan, dengan kata lain siswa kelas tinggi belum bisa mengkondisikan situasi yang mereka hadapi.

Hasil analisis hubungan kecerdasan emosional dengan kedisiplinan siswa kelas tinggi SD Negeri Se-Gugus Barenglor Klaten adalah sebesar 0,823 dengan taraf signifikansi 5\%. Berdasarkan data tersebut dapat dijelaskan bahwa ada hubungan positif antara kecerdasan emosional dengan kedisiplinan siswa kelas tinggi SD Negeri Se-Gugus Barenglor Klaten. Berdasarkan hasil tersebut dapat diketahui bahwa kecerdasan emosional memiliki relevansi dengan kedisiplinan sesuai dengan yang dikemukakan oleh Ambarkathi \& Nurjanah (2017) bahwa kecerdasan emosional membantu seseorang ketika melakukan serta memotivasi untuk berperilaku disiplin dalam menjalankan kehidupan. Hal tersebut sejalan dengan pendapat yang dikemukakan oleh Wizman (2017, p.136) bahwa seseorang yang memiliki kecerdasan emosi yang tinggi akan mempunyai sikap disiplin yang kuat. Begitu pula sebaliknya orang yang berjiwa disiplin pasti dapat mengatur emosinya dan kehidupannya dengan lebih baik.

Nilai korelasi sebesar 0,823 menunjukkan korelasi yang sangat kuat antara kecerdasan emosional dengan kedisiplinan siswa kelas tinggi SD Negeri Se-Gugus Barenglor .Hal ini juga menegaskan bahwa kecerdasan emosional berdistribusi dalam perkembangan pendidikan karakter 
khususnya karakter kedisiplinan. Sejalan dengan yang disampaikan oleh Goleman (2000, p.44) bahwa kecerdasan emosional berperan sangat penting dalam perkembangan pendidikan karakter.

\section{SIMPULAN}

Berdasarkan hasil penelitian serta pembahasan yang telah diuraikan, maka dapat disimpulkan bahwa variabel kecerdasan emosional memiliki hubungan yang positif dengan kedisiplinan. Hasil uji korelasi menunjukkan $\mathrm{r}_{\text {hit }}$ sebesar 0,823 , nilai tersebut mendekati 1 sehingga dapat dinyatakan bahwa terdapat hubungan positif. Nilai korelasi berada di rentang sangat kuat dengan berada dalam 0,800-1,00. Hal tersebut membuktikan bahwa terdapat hubungan yang positif antara kecerdasan emosional dengan kedisiplinan siswa kelas tinggi SD se-Gugus Barenglor Klaten, sehingga apabila siswa memiliki kecerdasan emosional yang dimiliki siswa tinggi, maka kedisiplinan siswa juga akan tinggi begitupun sebaliknya, apabila kecerdasan emosional yang dimiliki siswa rendah maka kedisiplinan siswa juga rendah. Hasil penelitian menunjukkan bahwa terdapat hubungan positif antara kecerdasan emosional dengan kedisiplinan siswa kelas tinggi SD se-Gugus Barenglor. Hal tersebut mengandung implikasi agar kedepannya orang tua serta guru mampu mengetahui dan mengembangkan kecerdasan emosional sejak dini agar nantinya dapat meningkatkan kedisiplinan yang dimiliki oleh siswa.

Berdasarkan hasil dari penelitian diharapan guru dapat ikut serta dalam pengembangan kecerdasan emosional siswa, khususnya dalam setiap pembelajaran dengan demikian siswa mampu mengontrol emosi serta meningkatkan kedisiplinan yang dimiliki siswa. Bagi orangtua dapat memberikan stimulus yang tepat bagi anak agar nantinya kecerdasan emosional yang dimiliki anak semakin meningkat serta orangtua dapat menerapkan kedisiplinan sejak dini di kehidupan seharihari agar anak semakin terbiasa misalnya dengan membiasakan anak bangun pagi serta membantu dalam mebereskan rumah merupakan kegiatan yang dapat meningkatkan stimulus dan karakter kedisiplinan anak.

\section{DAFTAR PUSTAKA}

Ambarkathi, T., \& Nurjanah. (2017). Hubungan Antara Kecerdasan Emosional Dengan Kedisiplinan Pada Tata Tertib Siswa Smp Negeri 3 Kalasan. Jurnal Bimbingan dan Konseling Dakwah Islam, Vol. 14, No. 2.

Ampuni, S., \& Andayani, B.(2015). Memahami Anak dan Remaja dengan Kasus Mogok Sekolah : Gejala, Penyebab, Struktur Kepribadian, Profit Keluarga, dan Keberhasilan Penanganan. Jurnal Psikologi, Vol. 34, No. 1, 55-75.

Efendi, A. (2005). Revolusi Kecerdasan Abad 21. Bandung: Alfabeta.

Goleman, D. (2000). Emotional Intelligence. Jakarta : PT Gramedia Pustaka Utama

Goleman, D. (2009). Emotional Intelligence. Jakarta : PT Gramedia Pustaka Utama

Karlinawati, L. (2015). Hubungan Antara Kecerdasan Emosional Dengan Sikap Percaya Diri Kelas VI SDN Cimpaeun I, Kecamatan Tapos, Kota Depok. Jurnal Pendidikan Guru Sekolah Dasar. Vol. 2, No. 2.

Lewis, R. (2004). Dilema Kedisiplinan: Kontrol, Manajemen, Pengaruh. (Terjemahan Emalia Iragiliati Lukman). Jakarta: Grasindo. (Edisi asli diterbitkan tahun 1997 oleh Australian Council for Educational Research, Victoria)

Mahaerni, N. (2016). Hubungan Kecerdasan Emosi Dengan Prestasi Belajar MatematikaSiswa Kelas V Sekolah Dasar Se-Gugus I Kecamatan Wates Kabupaten Kulon Progo Tahun Ajaran 2015/2016. Jurnal Pendidikan Guru Sekolah Dasar, Vol. 5. No. 4.

Manizar H. M. (2016). Mengelola Kecerdasan Emosional. Tadrib Jurnal Raden Fatah, Vol. 2, No.2, 198-213. 
Megawangi, R. (2007). Pendidikan Karakter: Solusi yang Tepat untuk Membangun Bangsa. Jakarta: Indonesia Heritage Foundation.

Moenir, A.S. (2010). Manajemen Pelayanan Umum di Indonesia. Jakarta : Bumi Aksara

Munawaroh, S. (2013). Perilaku Disiplin dan Kejujuran Generasi Muda di Daerah Istimewa Yogyakarta . Yogyakarta: Balai Pelestarian Nilai Budaya (BPNB)

Naim, N. (2012). Charachter Building. Yogyakarta: Ar-Ruzz Media

Narwanti, S. (2011). Pendidikan Karakter. Yogyakarta: Familia.

Pangestu, C., Sujati, H., Herwin, H. (2020). Pengaruh self efficacy dan pengasuhan orang tua terhadap keercayaan diri siswa. FOUNDASIA, 11(1), 35-42.

Purwaningsih, A. Y., \& Herwin, H. (2020). Pengaruh regulasi diri dan kedisiplinan terhadap kemandirian belajar siswa di sekolah dasar. Jurnal Penelitian Ilmu Pendidikan, 13(1), 2230. doi: https://doi.org/10.21831/jpipfip.v13i1.29662.

Rochimi, I. F., \& Suismanto. (2018). Upaya Guru Menanamkan Kedisiplinan Pada Anak Usia Dini. Jurnal Ilmiah Tumbuh Kembang Anak Usia Dini, Vol. 3, No. 4, 231-246.

Saputri, D. I., \& Herwin. (2020). The Effect of the Spirit of Nationalism and Cinta Tanah Air on The Self Independence of Elementary School Students. JMIE: Journal of Madrasah Ibtidaiyah Education, 4(1), , 114-126. jmie.v4i1.162.

Sulistyowati, S. (2001) . Cara Belajar yang Efektif. Pekalongan: Cinta Ilmu.

Tjabolo, S. A., \& Herwin.(2020). The Influence of Teacher Certification on the Performance of Elementary School Teachers in Gorontalo Province, Indonesia. International Journal of Instruction, 13(4), 347-360.

Tu'u, T. (2004). Peran Disiplin dalam Perilaku dan Prestasi Siswa. Jakarta:Grafindo

Wizman. (2017). Hubungan Antara Kecerdasan Emosional Dengan Kedisiplinan Belajar Siswa Kelas VI SDN 050607 Balai Kasih Kecamatan Kuala Kabupaten Langkat. Jurnal Handayani, Vol. 7, No. 1.

Zuriah, N. (2011). Pendidikan Moral dan Budi Pekerti dalam Perspektif Perubahan: Menggagas Platform Pendidikan Budi Pekerti Secara Kontekstual dan Futuristik. Jakarta: Bumi Aksara. 